\title{
PEMBERDAYAAN MASJID DI DESA BATURETNO, BANGUNTAPAN, YOGYAKARTA UNTUK KEMANDIRIAN UMAT
}

\author{
Oleh: \\ Megawati, S.H., M.Hum. dan mahasiswa KKN Alternatif divisi III.A \\ Universitas Ahmad Dahlan Yogyakarta \\ E-mail: fiqirozi@gmail.com
}

\begin{abstract}
Ringkasan
Salah satu visi Desa Baturetno dijadikan sebagai program KKN Alternatif Universitas Ahmad Dahlan Periode LVI tahun akademik 2016/2017 yaitu mewujudkan desa yang maju, asri, agamis, sejahtera, dan rukun. Penyelenggaraan program KKN Alternatif UAD Periode LVI tersebut bertujuan untuk memberdayakan dan meningkatkan fungsi masjid di Desa Baturetno. Oleh karena itu, program tersebut dapat menjadikan masyarakat Desa Baturetno sebagai umat yang mandiri, salah satunya yaitu memiliki jiwa untuk memakmurkan masjid. Sementara itu, metode pelaksanaan program KKN meliputi pendidikan masyarakat, motivasi, difusi teknologi, permainan, dan perlombaan. Hasil dari kegiatan KKN ini adalah 1) tercipta kesadaran remaja untuk melakukan kreativitas dengan menjauhi perbuatan negatif; 2) peningkatan semangat anak-anak untuk mengikuti TPA; dan 3) peningkatan semangat warga untuk membuat berbagai jenis usaha. Dengan demikian, program KKN Alternatif Universitas Ahmad Dahlan periode LVI tahun akademik 2016/2017 dalam pemberdayaan masjid di Desa Baturetno telah terlaksana dengan baik.
\end{abstract}

Kata kunci : Baturetno, Masjid, Pemberdayaan.

\begin{abstract}
Abstrak
One of the vision of Baturetno Village was made as KKN Alternatif program of Universitas Ahmad Dahlan Periode LVI of academic year 2016/2017 that is to realize the advanced, beautiful, religious, prosperous and harmonious village. Implementation of the Alternative KKN UAD program The LVI period is aimed at empowering and improving the function of mosques in Baturetno Village. Therefore, the program can make the community of Baturetno Village as an independent people, one of which is having a soul to prosper the mosque. Meanwhile, the methods of KKN program implementation include community education, motivation, technological diffusion, games, and competitions. The results of this KKN activity are 1) created adolescent awareness to do creativity by avoiding negative deeds; 2) increase the spirit of children to follow TPA; and 3) increasing the spirit of citizens to make various types of business. Thus, the Alternative KKN program of Ahmad Dahlan University LVI period of academic year 2016/2017 in empowering mosque in Baturetno Village has been done well.
\end{abstract}

Keywords: Baturetno, Mosque, Empowerment,

\section{A. PEndahuluan}

Desa Baturetno merupakan salah satu desa dari Kecamatan Banguntapan yang memiliki luas wilayah 3.711.730 ha. Jumlah penduduk Desa Baturetno sebanyak 15.375 jiwa yang terdiri dari laki-laki 7.808 jiwa dan perempuan 7.567 jiwa. Untuk bidang mata pencarian, sebagian besar sebagai wiraswasta dan buruh harian lepas. Desa Baturetno merupakan desa yang terletak $\pm 1 \mathrm{~km}$ dari pusat pemerintahan kecamatan. Secara administratif, batas-batas Desa Baturetno adalah sebagai berikut. 
Sebelah utara

Sebelah selatan

Sebelah barat

Sebelah timur
: Desa Banguntapan, Bantul

: Desa Potorono, Banguntapan bantul

: Desa Banguntapan, Bantul

: Desa Sendangtirto, Berbah, Sleman

a. Data penduduk Desa Baturetno

1. Jumlah Penduduk Berdasarkan Gender

\begin{tabular}{|c|l|c|}
\hline No. & \multicolumn{1}{|c|}{ Indikator } & Jumlah \\
\hline 1. & Jumlah penduduk & 15.369 orang \\
\hline 2. & Jumlah laki - laki & 7.564 orang \\
\hline 3. & Jumlah perempuan & 7.805 orang \\
\hline 4. & Jumlah Kepala Keluarga & $4772 \mathrm{KK}$ \\
\hline
\end{tabular}

2. Bidang Pendidikan

\begin{tabular}{|c|l|c|}
\hline No. & \multicolumn{1}{|c|}{ Pendidikan Penduduk } & Jumlah \\
\hline 1. & Belum sekolah & - orang \\
\hline 2. & Tidak pernah sekolah & - orang \\
\hline 3. & Tamat SD & 231 orang \\
\hline 7. & Tamat SLTP/SMP & 170 orang \\
\hline 9. & Tamat SLTA/SMA & 227 orang \\
\hline 10. & Tamat D-1-D-3 & 12 orang \\
\hline 13. & Tamat S-1 - S-3 & 13 \\
\hline
\end{tabular}

3. Keadaan Ekonomi

Mayoritas mata pencaharian penduduk Desa Baturetno adalah wirausaha dan buruh tani, sedangkan sebagian yang lain adalah PNS, guru, dan lain - lain :

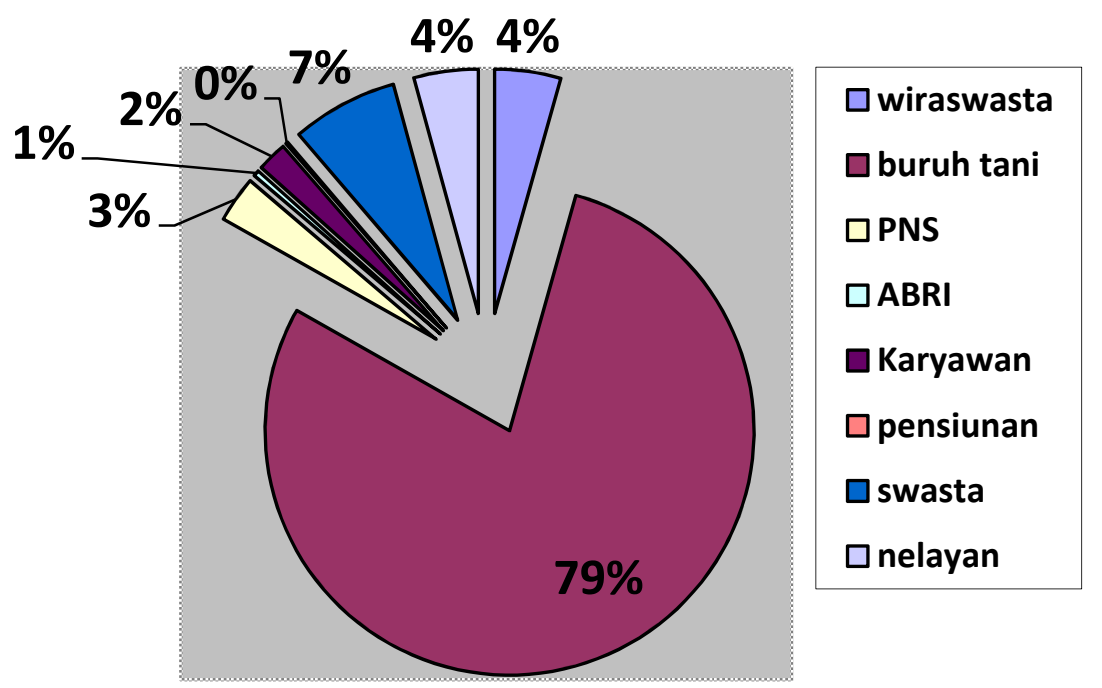

Gambar 1. Grafik keadaan ekonomi Desa Baturetno 
Visi pemerintah Desa Baturetno adalah mewujudkan Desa Baturetno yang maju, asri, agamis, sejahtera, rukun dengan mengedepankan ilmu pengetahuan dan teknologi. Adapun misi yang dilakukan untuk mencapai visi tersebut adalah (1) melaksanakan pelayanan administrasi pemerintahan dan keuangan melalui satu pintu yang akuntabel; (2) meningkatkan kualitas sumber daya manusia dan pelayanan terhadap masyarakat di berbagai bidang; (3) mengembangkan potensi desa dalam mengelola sumber daya alam dan sumber daya manusia; (4) meningkatkan dan memperkuat fungsi dan peran lembaga desa; (5) memperrkuat nilai-nilai luhur budaya gotong royong dalam membangun desa; (6) melestarikan budaya tradisi dan adat istiadat masyarakat; (7) mewujudkan suasana aman dan kondusif; (8) membentuk karakter berwira usaha dalam pengelolaan pemerintahan; (9) melestarikan budaya dan adat istiadat masyarakat; (10) mewujudkan suasana aman dan kondusif; dan (11) membentuk karakter berwira usaha dalam pengelolaan pemerintahan, kelembagaan, dan kemasyarakatan.

Beberapa permasalahan yang ditemukan di Desa Baturetno adalah (1) dampak klitih yang memengaruhi remaja; (2) menurunnya semangat anak-anak untuk mengikuti TPA; (3) menurunnya semangat warga untuk ke masjid; (4) kurangnya keterampilan warga; (5) belum adanya plangisasi; dan (6) minimnya partisipasi remaja dalam memajukan TPA.

Peran serta masyarakat dalam upaya memakmurkan masjid merupakan kesediaan masyarakat untuk membantu berhasilnya program sesuai dengan kemampuan setiap orang tanpa mengorbankan kepentingan diri sendiri. Masjid adalah suatu bangunan tempat suci, tempat untuk bersujud bagi orang-orang Islam, dan masjid merupakan benda mati yang tergantung pada orang-orang Islam untuk menjadikan masjid menjadi tempat yang dicintai oleh jamaahnya. Hal ini berarti menimbulkan peran takmir masjid untuk mengupayakan agar masjid dapat memberikan dampak positif bagi orang-orang Islam. Alasan orang-orang Islam terdorong pergi ke masjid dan terdapat suatu masjid yang tidak pernah sepi dari jamaah, baik itu untuk kepentingan menegakkan salat atau untuk mengikuti kegiatankegiatan yang bernapaskan Islam.

Namun sebaliknya, ada juga masjid yang sepi dari jamaah, bahkan lingkungannya terkesan kumuh dan kotor. Oleh karena itu, kita amati alasannya suatu masjid dicintai jemaah, tentunya ada sebab-sebab yang dapat mendorong jemaah mencintai masjid, di antaranya terjaga kebersihannya, pelayanan dalam bidang pembinaan mental spiritual, pemberdayaan zakat, infak dan sadaqah, tersedia taman baca, perpustakaan, majalah dinding, papan informasi, dan terjaga keamanannya (Affan, 2015).

Berdasarkan permasalahan tersebut, ditetapkan tujuan program KKN ini adalah memberdayakan masjid di Desa Baturetno, Kelurahan Baturetno, Kecamatan Banguntapan, Kabupaten Bantul untuk memakmurkan masjid dan memandirikan umat.

\section{B. METODE PELAKSANAAN}

Untuk mencapai tujuan yang diharapkan, program KKN Alternatif Universitas Ahmad Dahlan Periode LVI tahun akademik 2016/2017 di Desa Baturetno dilakukan dengan pemberdayaan masjid melalui pendidikan kepada masyarakat, motivasi, difusi ilmu 
pengetahuan, permainan dan perlombaan, dan praktik langsung. Ringkasan metode pelaksanaan beserta jam kerja efektif mahasiswa (JKEM) tersaji pada table 1 .

Tabel 1. Metode, Kegiatan, JKEM dan keterlibatan mahasiswa

\begin{tabular}{|c|c|c|c|c|}
\hline No & Metode & Kegiatan & JKEM & $\begin{array}{l}\text { Jumlah } \\
\text { mahasiswa } \\
\text { yang terlibat }\end{array}$ \\
\hline \multirow[t]{4}{*}{1} & $\begin{array}{l}\text { Pendidikan } \\
\text { masyarakat dan } \\
\text { motivasi }\end{array}$ & $\begin{array}{l}\text { Menyelenggarakan } \\
\text { penyuluhan kenakalan } \\
\text { remaja }\end{array}$ & $1 \times 3$ jam & 3 \\
\hline & & $\begin{array}{l}\text { Penyelanggaraan } \\
\text { pengajian untuk } \\
\text { masyarakat }\end{array}$ & 3x 1 jam & 9 \\
\hline & & $\begin{array}{l}\text { Pendampingan agenda } \\
\text { ramadan }\end{array}$ & $21 \times 1$ jam & 9 \\
\hline & & $\begin{array}{l}\text { Penyelenggaraan } \\
\text { sepeda sehat dalam } \\
\text { songsong ramadan }\end{array}$ & $1 \times 3$ jam & 9 \\
\hline 2 & Difusi iptek & $\begin{array}{l}\text { Menyelenggarakan } \\
\text { pengadaan taman } \\
\text { bacaan di masjid }\end{array}$ & $1 \times 3$ jam & 9 \\
\hline \multirow[t]{2}{*}{3} & $\begin{array}{l}\text { Permainan dan } \\
\text { perlombaan }\end{array}$ & $\begin{array}{l}\text { Penyelenggaraan } \\
\text { Festival anak saleh }\end{array}$ & $1 \times 3$ jam & 9 \\
\hline & & $\begin{array}{l}\text { Pengadaan Outbond } \\
\text { dan sepeda sehat } \\
\text { anak-anak }\end{array}$ & $1 \times 3$ jam & 9 \\
\hline \multirow[t]{3}{*}{3} & \multirow[t]{3}{*}{ Praktik } & $\begin{array}{l}\text { Pelatihan wudu, } \\
\text { tayamum dan salat }\end{array}$ & $1 \times 2 \mathrm{jam}$ & 4 \\
\hline & & Pelatihan tonis & $2 \times 2$ jam & 6 \\
\hline & & Pelatihan gerak lagu & $4 \times 1$ jam & 9 \\
\hline
\end{tabular}

\section{HASIL, PEMBAHASAN, DAN DAMPAK}

Setelah melakukan berbagai program, baik dari bidang keilmuan, keagamaan, seni dan olahraga, maupun tematik serta non tematik, hasil yang dicapai cukup baik. Hal ini terbukti dari antusiasme masyarakat. Untuk bidang keilmuan, sebelumnya anak-anak atau pelajar di Desa Baturetno belum menguasai materi-materi yang diajarkan di sekolah. Akan tetapi, setelah terlaksananya program bimbingan belajar, anak-anak sudah dapat menguasai berbagai materi. Materi yang dikuasai pun tidak hanya untuk satu mata pelajaran, tetapi 
Diterbitkan oleh Lembaga Pengabdian kepada Masyarakat Universitas Ahmad Dahlan Yogyakarta

mencakup berbagai mata pelajaran, seperti Matematika, Bahasa Indonesia, IPA, IPS, PKN, Bahasa Inggris, dan lain-lainnya. Jumlah anak pun semakin hari semakin bertambah. Hal ini terbukti dari salah satu grafik di Dusun Gilang sebagai berikut.

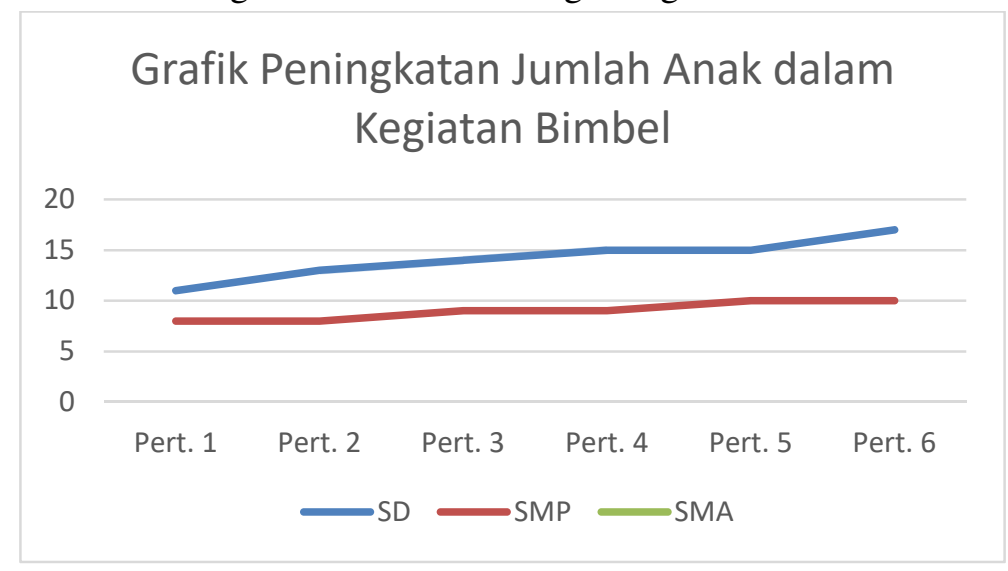

Gambar 2. Grafik Peningkatan Jumlah Anak dalam Kegiatan Bimbel

Selain bidang keilmuan, peningkatan juga terjadi dalam bidang tematik dan nontematik. Sebelumnya, masyarakat di Desa Baturetno belum mengetahui cara membuat berbagai keterampilan, seperti pembuatan sempol ayam, pembuatan tepung mocaf, pembuatan keset, pembuatan lampion dari benang, pembuatan lilin arome terapi, dan sebagainya. Namun setelah terlaksana program-program tersebut, masyarakat terlihat antusias. Bakhan, beberapa anggota masyarakat berniat mendirikan usaha kecil, salah satunya usaha suvenir lilin aroma terapi. Hal ini terbukti dari foto kegiatan berikut.
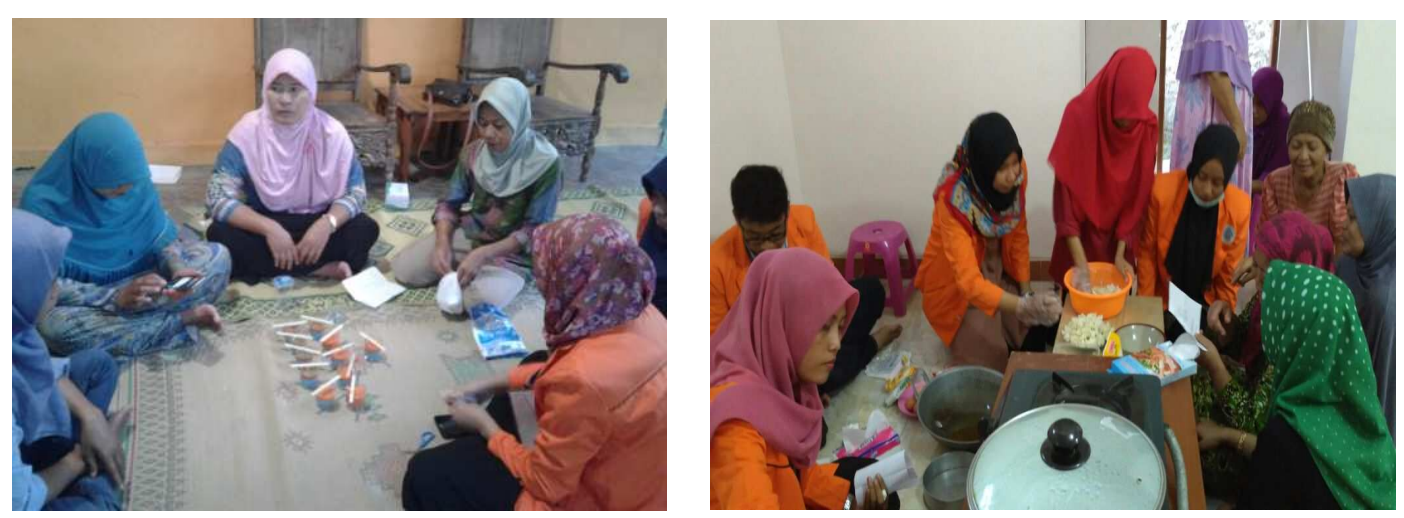

Gambar 3. Pelatihan Pembuatan Lilin Aroma Gambar 4 Pelatihan Pembuatan Nugget Terapi

Selain bidang tematik dan nontematik, peningkatan juga terjadi dalam bidang keagamaan. Sebelumnya, kuantitas masyarakat di Desa Baturetno untuk melaksanakan salat berjamaah sudah cukup baik. Akan tetapi setelah mahasiswa KKN Alternatif UAD periode LVI tahun 2016/2017 melaksnaakan program pengajian, kuantitas jamaah terlihat meningkat. Selain itu, anak-anak yang mengikuti TPA juga mulai bertambah karena mahasiswa UAD ini juga mengajak kepada anak-anak untuk mengikuti TPA. Anak-anak terlihat antusias dalam kegiatan TPA. Hal ini terlihat dari grafik berikut. 


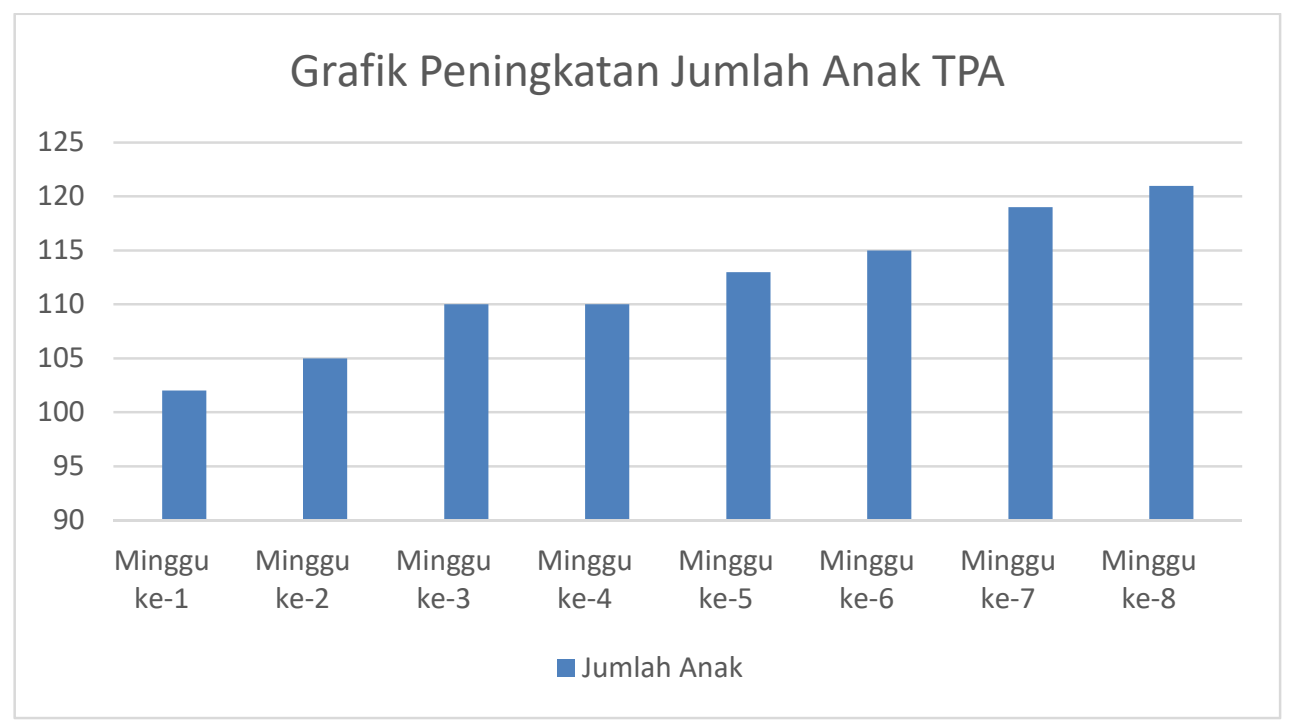

Gambar 5 Grafik Peningkatan Jumlah Anak TPA

Selain kegiatan di atas, masih banyak program-program yang dilaksanankan oleh mahasiswa. Aktivitas mahasiswa KKN UAD dan masyarakat Desa Baturetno dalam program pendidikan masyarakat dan motivasi tersaji pada gambar 6 berikut.
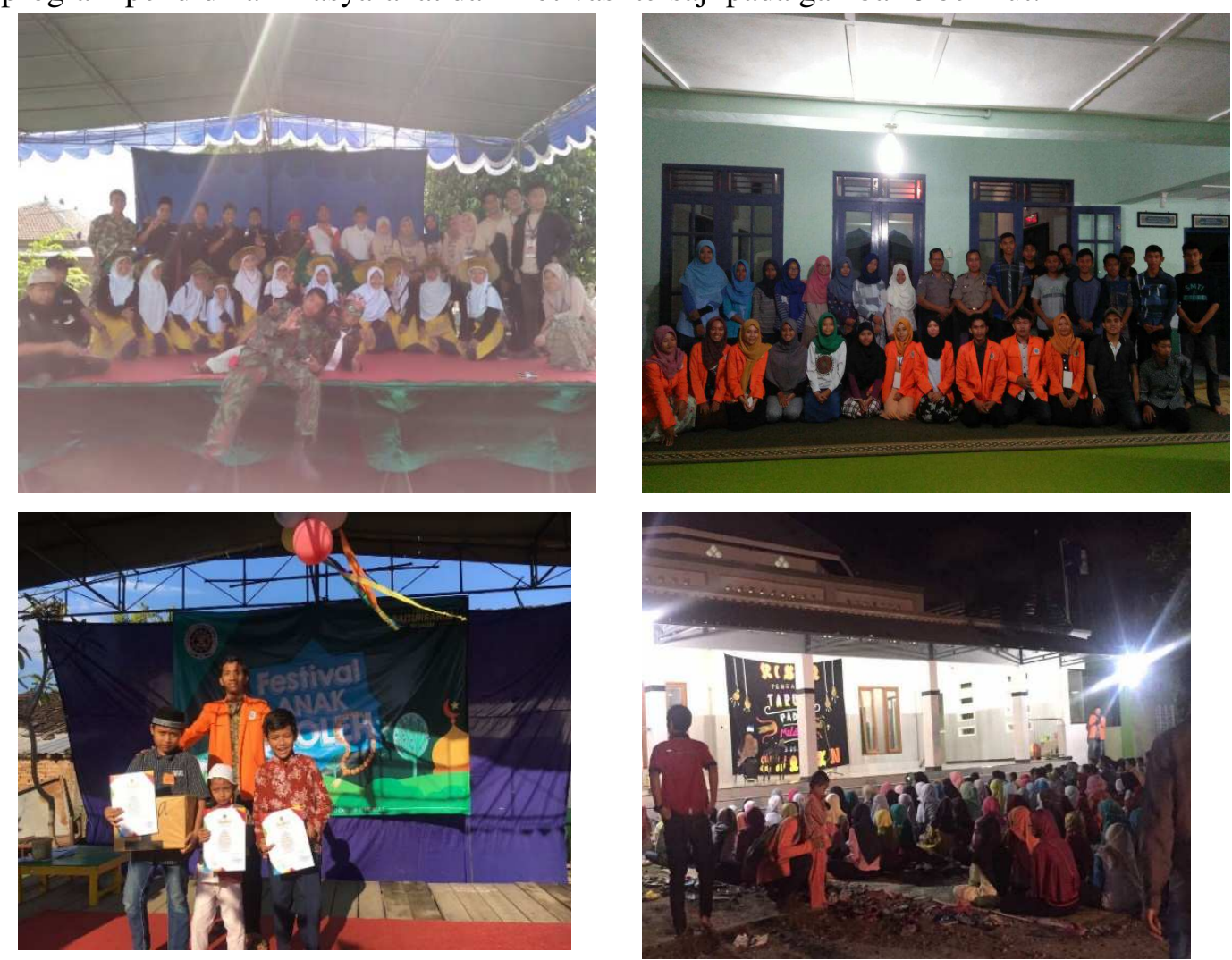

Gambar 6. Aktivitas mahasiswa KKN UAD dan masyarakat Desa Baturetno dalam program pendidikan masyarakat dan motivasi 
Diterbitkan oleh Lembaga Pengabdian kepada Masyarakat

Universitas Ahmad Dahlan Yogyakarta

\section{KESIMPULAN}

Dengan demikian, program KKN Alternatif Universitas Ahmad Dahlan periode LVI tahun akademik 2016/2017 dalam pemberdayaan masjid di Desa Baturetno untuk kemandirian umat telah terlaksana dengan baik.

\section{DAFTAR PUSTAKA}

Affan, 2015, Usaha mewujudkan masjid dalam upaya dicintai jamaah. http://www.untajiaffan.com/2015/03/usaha-mewujudkan-masjid-dicintaijemaah.html (Diakses tanggal 17 Juli 201) 
